\title{
MDR1 is Related to Intestinal Epithelial Injury Induced by Acetylsalicylic Acid
}

\author{
Munehiro Kugaia Kazuhiko Uchiyama ${ }^{a}$ Toshifumi Tsujia Hiroyuki Yorikia \\ Akifumi Fukui ${ }^{a}$ Ying Qin ${ }^{a}$ Yasuki Higashimura ${ }^{a}$ Katsura Mizushima ${ }^{a}$ \\ Naohisa Yoshida ${ }^{a}$ Kazuhiro Katada ${ }^{a}$ Kazuhiro Kamada ${ }^{a}$ Osamu Handa ${ }^{a}$ \\ Tomohisa Takagia Hideyuki Konishia Nobuaki Yagia Toshikazu Yoshikawa ${ }^{a}$

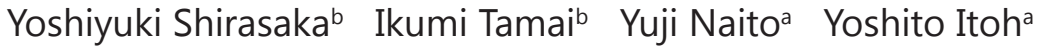 \\ aMolecular Gastroenterology and Hepatology, Kyoto Prefectural University of Medicine, Kyoto, \\ ${ }^{b}$ Faculty of Pharmacy, Institute of Medical, Pharmaceutical and Health Sciences, Kanazawa University, \\ Kanazawa, Japan
}

\section{Key Words}

MDR1 • Aspirin • Intestinal epithelial injury

\begin{abstract}
Background/Aims: Although the cytotoxicity of aspirin against the intestinal epithelium is a major clinical problem, little is known about its pathogenesis. We assessed the involvement of Multi Drug Resistance (MDR) 1 in intestinal epithelial cell injury caused by aspirin using MDR1 gene-transfected $\mathrm{CaCO} 2$ cells. Methods: $\mathrm{CaCO} 2$ cells were treated with various concentrations of aspirin for $24 \mathrm{~h}$. After treatment of Caco2 cells with verapamil, a specific inhibitor of MDR1, we assessed the extent of cell injury using a WST-8 assay at $24 \mathrm{~h}$ after aspirin-stimulation. We performed the same procedure in MDR1 gene-transfected Caco2 cells. To determine the function of MDR1 in the metabolism of aspirin, flux study was performed using ${ }^{14} \mathrm{C}$-labeled aspirin. Results: The level of aspirin-induced cell injury was higher in verapamil-treated Caco2 cells than in control cells and was less serious in MDR1-transfected Caco2 cells than in control vector-transfected cells. The efflux of ${ }^{14} \mathrm{C}$-labeled aspirin was higher in verapamil-treated Caco2 cells than in control cells. Conclusion: These data suggest that aspirin efflux occurs through the MDR1 transporter and that the MDR1 transporter is involved in the pathogenesis of aspirin-induced cell injury.
\end{abstract}

Copyright $(2013$ S. Karger AG, Basel

\section{Introduction}

The clinical use of aspirin has increased because of the general aging of the population and the increasing prevalence of atherosclerosis and diabetes, which are risk factors for ischemic cardiovascular disease [1]. The development of endoscopic diagnostic techniques, 
such as video capsule endoscopy and balloon enteroscopy, for small intestinal diseases has provided clear evidence that aspirin can induce intestinal mucosal injury in addition to gastric injury [2]. Although the pathophysiology of aspirin-induced intestinal epithelial cellular injuries has been extensively researched and clarified, practical therapies for such injuries are unavailable. Therefore, it is important to develop preventive and therapeutic strategies for aspirin-induced intestinal epithelial cellular injuries.

The Multi Drug Resistance (MDR) transporter encoded by the MDR1 gene belongs to the adenosine triphosphate (ATP)-binding cassette (ABC) superfamily of membrane transporters [3]. MDR1 was identified in a MDR strain of cancer [4]. However, MDR1 is also expressed in the brush border of the proximal tubule of the kidney and in the bile duct of liver cells, which play an important role in the excretion of endogenous substances, such as drugs and other substances [3]. Further, MDR1 is expressed at the apical (AP) surface tip of the mucosal epithelial cells in the small and large intestines [4], where it acts to export unnecessary or toxic exogenous substances or metabolites and where it may play a role in limiting the enteral absorption of a number of structurally unrelated drugs.

A recent report evaluated whether the genotypes of uptake and efflux transporters, including MDR1, are related to peptic ulcer and/or ulcer bleeding associated with aspirin use [5], but an association between MDR1 and aspirin-induced small intestinal epithelial cellular injury has not been reported. The present study investigated the role of MDR1 in aspirin-induced intestinal epithelial cellular injury using a pharmacological blocker of MDR1 in MDR1-overexpressing Caco2 intestinal epithelial cells.

\section{Materials and Methods}

\section{Cell culture}

The human colon carcinoma cell line, Caco2, was cultured in plastic dishes at $37^{\circ} \mathrm{C}$ in a humidified incubator with $5 \% \mathrm{CO}_{2} / 95 \%$ air in Dulbecco's Modified Eagle's Medium (Invitrogen/GIBCO, Grand Island, NY) supplemented with $10 \%$ fetal bovine serum, penicillin $(100 \mathrm{U} / \mathrm{mL})$, and streptomycin $(100 \mu \mathrm{g} / \mathrm{mL})$. Caco2 was cultured for 2 weeks to differentiate as intestinal epithelial cell.

\section{mRNA analysis}

The mRNA levels of MDR1 were determined by real-time polymerase chain reaction (PCR) from samples. Total RNA was isolated from samples by the acid guanidinium phenol chloroform method, using an ISOGEN kit (Nippon Gene, Tokyo, Japan). The concentration of RNA was determined by the absorbance at $260 \mathrm{~nm}$ in relation to that at $280 \mathrm{~nm}$. The isolated RNA was stored at $-80^{\circ} \mathrm{C}$ until it was used for the real-time PCR assay. Extracted RNA $(1 \mu \mathrm{g})$ was reverse-transcribed into first-strand cDNA at $42^{\circ} \mathrm{C}$ for 40 min, using $100 \mathrm{U} / \mathrm{mL}$ of reverse transcriptase (Takara Biomedicals, Shiga, Japan) and $0.1 \mu \mathrm{M}$ of oligo (dT)adapter primer (Takara Biomedicals) in a 50- $\mu \mathrm{L}$ reaction mixture. Real-time PCR for human MDR1 was carried out with a 7300 real-time PCR DNA-binding dye SYBR green I for the detection of PCR products. The reaction mixture (RT-PCR kit, Code RR043A; Takara Biochemicals) contained $12.5 \mu \mathrm{L}$ Premix Ex Taq, $2.5 \mu \mathrm{L}$ SYBR green I, custom-synthesized primers, ROX reference dye, and cDNA (equivalent to $20 \mathrm{ng}$ total RNA) in a final reaction volume of $25 \mu \mathrm{L}$. The PCR settings were as follows: initial denaturation for $15 \mathrm{~s}$ at $95^{\circ} \mathrm{C}$ was followed by 40 cycles of amplification for $3 \mathrm{~s}$ at $95^{\circ} \mathrm{C}$ and $31 \mathrm{~s}$ at $60^{\circ} \mathrm{C}$, with subsequent melting curve analysis increasing the temperature from $60^{\circ} \mathrm{C}$ to $95^{\circ} \mathrm{C}$. The primers had the following sequences: for MDR1, sense: 5'-GTC CCA GGA GCC CAT CCT-3', and antisense: 5'-CCC GGC TGT TGT CTC CAT A-3'; and for human $\beta$-actin, sense: 5'-TAT CCA CCT TCC AGC AGA TGT-3', and antisense: 5'-TAT CCA CCT TCC AGC AGA TGT-3'. Relative quantification of gene expression with real-time PCR data was calculated relative to $\beta$-actin.

\section{Western blot analysis}

For western blot analysis, samples were harvested and total proteins were mixed with sodium dodecyl sulfate (SDS) sample buffer. The samples were subjected to 7\% SDS-polyacrylamide gel electrophoresis (PAGE) and blotted onto a polyvinylidene difluoride (PVDF) membrane (Atto Corporation, Tokyo, Japan). The membrane was blocked with $2 \%$ bovine serum albumin in TBS-T (Tris-buffered saline and $0.1 \%$ Tween 
Kugai et al.: MDR1 Transport Aspirin and Protect Epithelial Cell

20) at room temperature for $30 \mathrm{~min}$. Western blotting was carried out using anti-MDR1 (P-gp) antibody (C219; Calbiochem, Darmstadt, Germany) at room temperature for $1 \mathrm{~h}$. After three washes with TBS-T, the membrane was incubated with anti-mouse IgG-HRP (NA934V; GE Healthcare UK, Ltd., Chalfont St. Giles, UK) at room temperature for $60 \mathrm{~min}$. The signals were visualized using an enhanced chemiluminescence (ECL) kit (GE Healthcare UK, Ltd.) according to the manufacturer's instructions.

\section{Cell viability assay}

Cell viability was assessed by use of the WST-8 labeling kit (Roche Diagnostics, Mannheim, Germany) at $24 \mathrm{~h}$ after treatment with aspirin and verapamil (or no treatment for control). The medium was removed, and $100 \mu \mathrm{L}$ of fresh medium with $10 \mu \mathrm{L}$ WST-8 labeling solution was added. Measurements (OD (optical density) $450 \mathrm{~nm}$ ) were taken after $1 \mathrm{~h}$ at $37^{\circ} \mathrm{C}$ via a microplate enzyme-linked immunosorbent assay (ELISA) reader.

\section{Cell death assay}

After exposure to an additional $20 \mathrm{mM}$ aspirin for $24 \mathrm{~h}$, the cells were stained in the culture medium with $0.15 \mathrm{mg} / \mathrm{mL}$ of Hoechst 342 . In Hoechst 342 staining, chromatin agglutination cells were counted in 10 randomly selected fields of vision, and the ratio of chromatin agglutinated cells to normal cells was calculated.

\section{Transfection of Caco2 cells with an MDR1 expression vector}

Human cDNA was subcloned into pcDNA and transfected into Caco2 cells using the polyamine-derived reagent LT-1 (Mirus, Madison, WI). Clones were selected on the basis of G418 (600 $\mu \mathrm{g} / \mathrm{mL})$ resistance and were individually propagated for flux studies. The degree of MDR1 transfection of cells was assessed by measuring digoxin efflux by MDR1 protein western blotting and by determination of MDR1 mRNA levels by PCR.

\section{Transport experiments}

$\left[\right.$ Acetyl- $\left.{ }^{14} \mathrm{C}\right]$ acetylsalicylic acid $\left({ }^{14} \mathrm{C}\right.$-aspirin) was purchased from American Radiolabeled Chemicals (St. Louis, MO). Caco2 cells were grown in Transwell inserts. A monolayer of Caco2 cells was preincubated in transport medium (Hank's balanced salt solution; $0.952 \mathrm{mM} \mathrm{CaCl}_{2}, 5.36 \mathrm{mM} \mathrm{KCL}, 0.441 \mathrm{mM} \mathrm{KH}_{2} \mathrm{PO}_{4}, 0.812$ $\mathrm{mM} \mathrm{MgSO}_{4}, 136.7 \mathrm{mM} \mathrm{NaCl}, 0.385 \mathrm{mM} \mathrm{Na}_{2} \mathrm{HPO}_{4}, 25 \mathrm{mM}$ D-glucose, and $10 \mathrm{mM}$ HEPES, $\mathrm{pH}$ 7.4) for $30 \mathrm{~min}$ at $37^{\circ} \mathrm{C}$. After pre-incubation, the transepithelial electrical resistance (TEER) was measured routinely with a Millicell-ERS system (Millipore Corporation, Bedford, MA) before experiments to ensure cell monolayer integrity. Caco 2 cells that exhibited TEER values higher than $300 \Omega / \mathrm{cm}^{2}$ were used for transport experiments. Transport measurement was initiated by adding aspirin $(1 \mathrm{mM})$ to the donor side and transport medium to the receiver side. Transport of aspirin was measured in two directions, apical (AP) to basolateral (BL) and BL to AP. An aliquot of transport buffer was obtained from the donor side at $5 \mathrm{~min}$ for measurement of initial concentration and from the receiver side at 30, 60, 90, and $120 \mathrm{~min}$. Transport experiments were performed under the same $\mathrm{pH}$ conditions ( $\mathrm{AP} \mathrm{pH}=7.4, \mathrm{BL} \mathrm{pH}=7.4$ ). All experiments were performed in a $37^{\circ} \mathrm{C} \mathrm{room}$.

The apparent permeability coefficient $\left(\mathrm{P}_{\mathrm{app}}, \mathrm{cm} / \mathrm{s}\right)$ was calculated from the following equation:

$$
P_{\mathrm{app}}=\left(\frac{\mathrm{dQ} / \mathrm{dt}}{C_{0} X \mathrm{~A}}\right)
$$

where $d Q / d t$ is the rate of permeation of aspirin across cell monolayers, $C_{0}$ is the initial concentration of aspirin in the donor compartment $(\mu \mathrm{M})$, and $A$ is the membrane surface area $\left(0.9 \mathrm{~cm}^{2}\right.$ in the present study). An efflux ratio is calculated from the mean AP to BL (A-B) $P_{\text {app }}$ data and BL to AP (B-A) $P_{\text {app }}$ data from the following equation:

$$
\text { Efflux ratio }=\frac{P_{\text {app }}(B-A)}{P_{a p p}(A-B)}
$$

Flux study

Caco2 cells were grown in 12-well plastic plates until differentiated, and then half of them were treated with $10 \mu \mathrm{M}$ of verapamil-conditioned medium. The other half was treated with verapamil-free medium for 


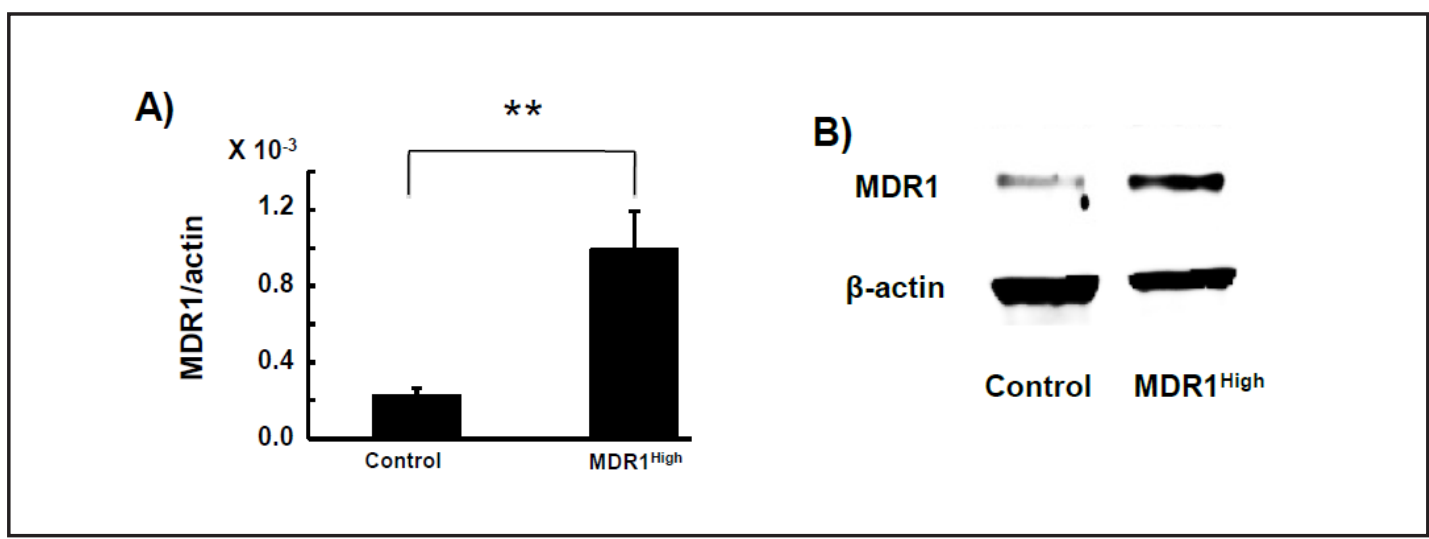

Fig. 1. MDR1 mRNA levels (A) and MDR1 protein levels (B) in MDR1 ${ }^{\text {High }}$ Caco2 cells and control vectortransfected cells $\left({ }^{* *} \mathrm{p}<0.01\right)$. Both mRNA and protein levels were higher in MDR1 ${ }^{\text {High }}$ cells than in control cells. Statistical significance was determined by ANOVA followed by Tukey's HSD test.

$24 \mathrm{~h}$. Cells were loaded with aspirin ( $1 \mathrm{mM}$ ) for 30 or $60 \mathrm{~min}$. Medium was removed from the cells after 30 or $60 \mathrm{~min}$, cells were washed with ice-cold phosphate-buffered saline three times, and cells remaining in the plate were extracted with $1 \mathrm{~N} \mathrm{NaOH}$. The amounts of $\mathrm{C}^{14}$ in the cellular fractions were counted with a liquid scintillation counter (Tri-Carb 2700TR, Packard Instrument Company, Meriden, CT).

\section{Statistical analysis}

All results are expressed as means \pm standard error (SE). The data were compared by two-way analysis of variance (ANOVA), and differences were considered to be statistically significant if the P value was $<0.05$ based on Scheffe's multiple-comparison test. All analyses were performed using the StatView 5.0-J program (Abacus Concepts, Berkeley, CA).

\section{Results}

MDR1 expression in MDR1 ${ }^{\text {High }}$ cells

Real-time PCR and western blotting was performed to characterize the expression of MDR1 in MDR1 ${ }^{\text {High }}$ cells. Both $\mathrm{mRNA}$ and protein levels were higher in MDR1 ${ }^{\text {High }}$ cells than in control cells (Fig. 1A, 1B).

Cellular injury by aspirin, and protection by MDR1 overexpression

Aspirin treatment $(20 \mathrm{mM})$ resulted in a decrease of cellular viability by $60 \%$ when compared with non-treated control cells (Fig. 2A). Without aspirin treatment, the inhibition of MDR1 by verapamil and MDR1 overexpression (MDR1 $1^{\text {high }}$ ) did not affect cellular viability (Fig. 2B, four bars from the left). After aspirin treatment, verapamil potentiated the decrease in cellular viability in control cells. This decrease was reversed in MDR1 ${ }^{\text {High }}$ cells, an action which, in turn, was prevented by verapamil (Fig. 2B, four bars from the right).

\section{Cell death assay}

The proportion of cells with chromatin agglutination was higher in aspirin-treated control cells. Further, treatment with verapamil resulted in an increase in the proportion of cells with chromatin agglutination in both control and MDR1 $1^{\text {High }}$ cells without verapamil treatment. Aspirin-induced chromatin agglutination was attenuated in MDR1 $1^{\text {High }}$ cells (Fig. 2C, 2D), and this attenuated response was blocked by verapamil (Fig. 2C).

\section{Transport experiments}

When aspirin, including ${ }^{14} \mathrm{C}$-aspirin, was added to the AP side of Transwell inserts, the verapamil-treated cells showed higher concentration of aspirin in the BL side at $120 \mathrm{~min}$ 


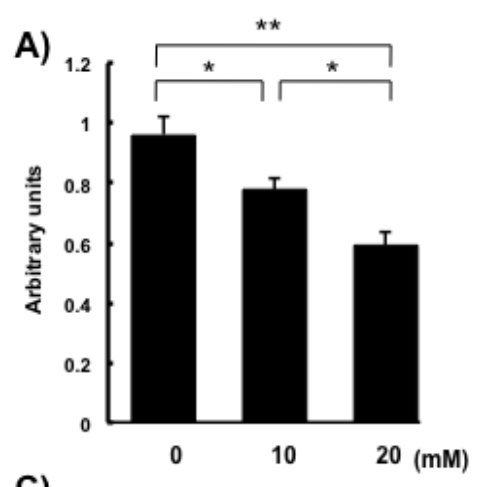

C)

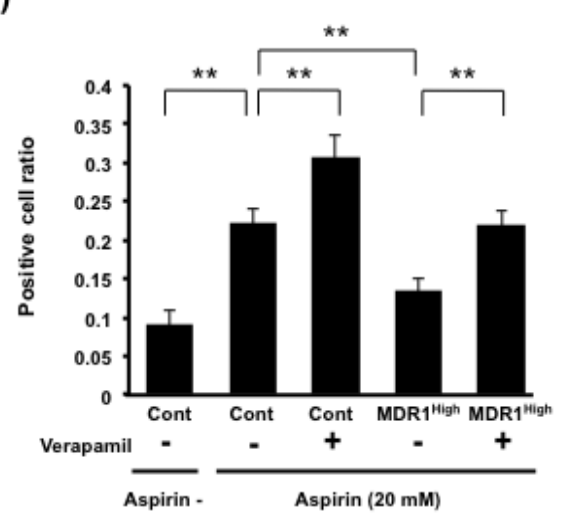

B)

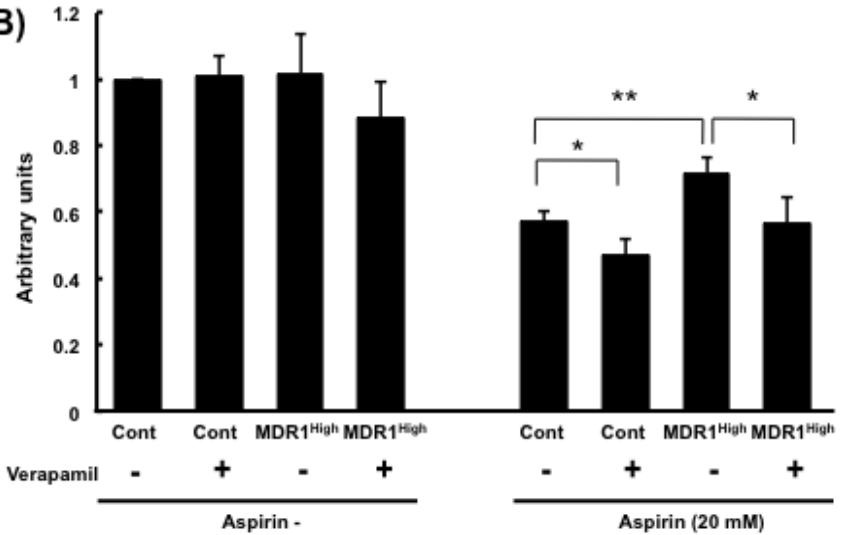

D)

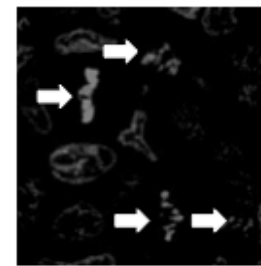

Cont

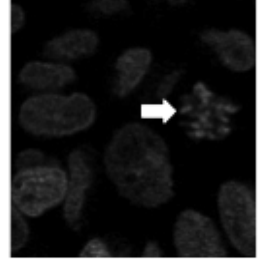

MDR1 High

Fig. 2. (A) Cellular viability determined by the WST- 8 assay in Caco 2 cells treated with aspirin treatment (10 and $20 \mathrm{mM})$. (B) Effect of verapamil on cellular viability in control vector-transfected cells and MDR1 ${ }^{\text {High }}$ cells. Values are means \pm SEM. Statistical significance was determined by ANOVA followed by Tukey's HSD test. Aspirin treatment (20 mM) resulted in a decrease in cellular viability. Without aspirin treatment, the inhibition of MDR1 by verapamil and MDR1 overexpression (MDR1 ${ }^{\text {high }}$ ) did not affect cellular viability. After aspirin treatment, verapamil potentiated the decrease in cellular viability in control cells. (C) In Hoechst 342 staining, chromatin agglutination cells were counted and used to calculate the ratio of chromatin-agglutinated cells to normal cells. Control cells and MDR $1^{\text {High }}$ cells were treated with aspirin (20 mM) and with or without verapamil. (D) Fluorescent microscopic image of aspirin-treated control cells and MDR1 ${ }^{\text {High }}$ cells. Each value indicates the mean \pm SE for five sets of experiments $\left({ }^{*} p<0.05,{ }^{* *} p<0.01\right)$. Statistical significance was determined by ANOVA followed by Tukey's HSD test. The proportion of cells with chromatin agglutination was higher in aspirin-treated control cells than verapamil-free cells. Treatment with verapamil resulted in an increase in the proportion of cells with chromatin agglutination in both control and MDR1 ${ }^{\text {High }}$ cells without verapamil treatment.

after aspirin treatment than verapamil-free cells (Fig. 3A). The assay was also performed in the opposite direction. Even at $120 \mathrm{~min}$, the AP concentration of aspirin was the same in both verapamil-treated and verapamil-free cells; at $30 \mathrm{~min}$ after aspirin treatment, AP concentrations of aspirin were significantly lower in verapamil-treated cells than in verapamil-free cells (Fig. 3B). These data indicate that the permeability of aspirin was significantly changed in both directions in response to verapamil treatment. Verapamil treatment also significantly lowered the efflux ratio of aspirin (Table 1).

Flux study

After $10 \mathrm{~min}$ of aspirin treatment, including ${ }^{14} \mathrm{C}$-aspirin, verapamil increased the concentration of aspirin in control cells. The concentration of aspirin was significantly lower 

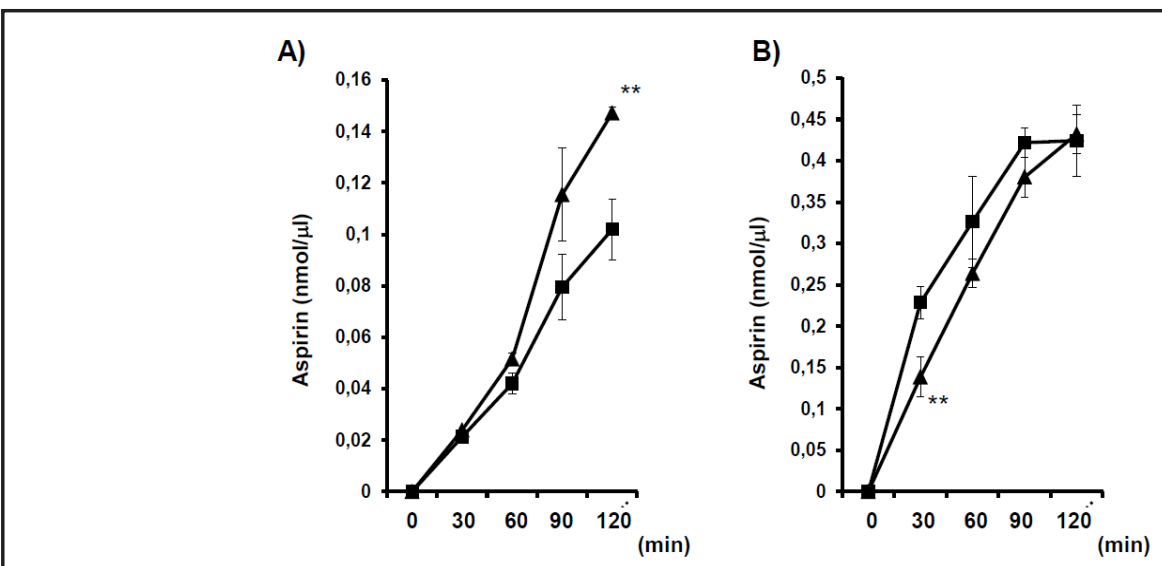

Fig. 3. The aspirin flux of control Caco2 cells and verapamil-treated Caco 2 cells. (A) Aspirin was added from the apical side, and ${ }^{14} \mathrm{C}$-aspirin was measured from the basolateral side of Transwell inserts ( $\mathbf{\Delta}$ : aspirin + verapamil, $\mathbf{\square}$ : aspirin only). (B) Aspirin was added from the basolateral side, and ${ }^{14} \mathrm{C}$-aspirin was measured from the apical side of Transwell insert ( $\mathbf{\Delta}$ : aspirin + verapamil, $\mathbf{\square}$ : aspirin only). Each value indicates the mean \pm SE for five sets of experiments $\left({ }^{* *} \mathrm{p}<0.01\right)$. Statistical significance was determined by ANOVA followed by Tukey's HSD test. When treated with verapamil, concentration of aspirin was higher in the BL side at $120 \mathrm{~min}$ after aspirin treatment than in verapamil-free cells. In the reverse experiment, apical concentrations of aspirin were significantly lower in verapamil-treated cells than in verapamil-free cells at $30 \mathrm{~min}$.

Table 1. Initial donor concentration of aspirin was $1 \mathrm{mM}$. Applied concentration of verapamil was 10 $\mu \mathrm{M} .{ }^{1}$ The permeability ratio was calculated as: (BL to $\mathrm{AP} / \mathrm{AP}$ to BL). Data are represented as means \pm SEM $(n=3)$. Statistical significance was determined by ANOVA followed by Tukey's HSD test. Verapamil treatment also significantly lowered the efflux ratio of aspirin.

Fig. 4. Intracellular aspirin concentration of control vector-transfected cells and MDR1 ${ }^{\text {High }}$ cells. ${ }^{14} \mathrm{C}$-aspirin was measured after $10 \mathrm{~min}$ of aspirin treatment with and without verapamil. Each value indicates the mean \pm SE for five sets of experiments $\left({ }^{* *} \mathrm{p}<0.01\right)$. Statistical significance was determined by ANOVA followed by Tukey's HSD test. After 10 min of aspirin treatment, verapamil increased the concentration of aspirin in control cells. The concentration of aspirin was significantly lower in MDR1 ${ }^{\text {High }}$ cells than in control cells. Verapamil treatment increased the concentration of aspirin in MDR1 $1^{\text {High }}$ cells.

\begin{tabular}{|c|c|c|c|}
\hline \multirow[t]{2}{*}{ Aspirin } & \multicolumn{2}{|c|}{$\operatorname{Papp}\left(10^{-6} \mathrm{~cm} / \mathrm{s}\right)$} & \multirow[t]{2}{*}{ 1Ratio } \\
\hline & AP to BL & BL to AP & \\
\hline Alone & $1.31 \pm 0.15$ & $5.64 \pm 0.47$ & 4.28 \\
\hline + verapamil & $1.47 \pm 0.09$ & $3.41 \pm 0.59$ & 2.38 \\
\hline
\end{tabular}

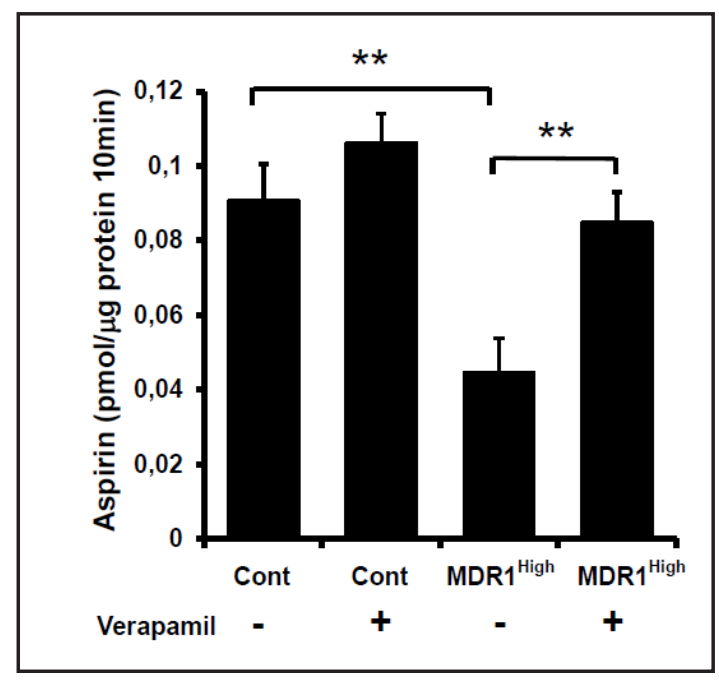

in MDR1 ${ }^{\text {High }}$ cells than in control cells. Verapamil treatment increased the concentration of aspirin in MDR1 ${ }^{\text {High }}$ cells (Fig. 4). 


\section{Discussion}

Nonsteroidal anti-inflammatory drugs (NSAIDs), including aspirin, inhibit the production of prostaglandins (PGs). In the gastrointestinal tract, PGs are very important mediators of mucosal defense and repair. Suppression of PG synthesis is the key effect of NSAIDs that leads to gastrointestinal mucosal injury [6]. The present study demonstrated that the cellular viability of Caco2 intestinal epithelial cells decreased in response to aspirin treatment in a concentration-dependent manner and that aspirin predominantly induced apoptosis in these cells. The increase in apoptotic cell death was significantly enhanced by co-treatment with verapamil, a blocker of MDR1, and was reversed in MDR1 ${ }^{\text {High }}$ cells. The transport study and the flux study using ${ }^{14} \mathrm{C}$-aspirin confirmed that aspirin is a substrate of MDR1 and that the intracellular concentration of aspirin was regulated by transmembrane passive diffusion as well as transport through MDR1. These results suggest that the induction or overexpression of MDR1 in the small intestine could suppress aspirin-induced small intestinal epithelial cellular injury.

Oral administration of aspirin does not cause small intestinal epithelial cellular injury directly, because aspirin is rapidly absorbed from the stomach and duodenum under acidic conditions and because of the lack of enterohepatic recirculation [7]. However, recent enteroscopic studies have clearly demonstrated that low-dose aspirin (usually entericcoated) induces hemorrhagic lesions, including ulcers and bleeding, in the small intestine in patients. Using capsule endoscopy, Endo et al. [8] demonstrated that enteric-coated aspirin might be more injurious to the small intestine than buffered aspirin. Nonoyama et al. [9] clearly showed that the injection of aspirin into the duodenum could induce intestinal hemorrhagic lesions in rats. These data suggest that aspirin must interact directly with the intestinal mucosa to produce injury. Although the concentration of aspirin in human plasma is extremely low because of hydrolysis [10], the mucosal concentration of aspirin might be much higher, especially in patients treated with enteric-coated aspirin. Studies of the oral administration of aspirin in rats have shown that aspirin causes gastric injury in the stomach at concentrations between 10 and $100 \mathrm{mM}$ [11]. In addition, aspirin could induce cell death in Caco 2 cells at concentrations of $5 \mathrm{mM}$ [12]. Therefore, the concentrations of aspirin used in this study (10 and $20 \mathrm{mM}$ ) might be physiologically relevant to those used in previous studies. The present study demonstrated the dose-dependent cytotoxic effects of aspirin on differentiated Caco2 cells, which have features of human epithelial cells of the small intestine, and confirmed that aspirin predominantly induced apoptosis in these cells according to biochemical and morphological analysis for cellular death. Further, this study demonstrated that the decrease in cell viability and the increase in apoptotic cells in Caco2 cells treated with aspirin were potentiated in cells co-treated with verapamil, a blocker of MDR1. By contrast, the decrease in cell viability did not occur in MDR1 ${ }^{\text {High }}$ cells. Finally, this study confirmed that neither verapamil alone nor MDR1 transfection alone affected cell viability of Caco2 cells in the absence of aspirin. These results indicate that MDR1 plays a critical role in the pathogenesis of aspirin-induced apoptotic cell death of small intestinal epithelial cells.

Human MDR1 encodes a drug transporter p-glycoprotein with very broad substrate specificity. Various compounds with different structures and properties are transported by p-glycoprotein. This study utilized transport experiments and flux experiments using ${ }^{14} \mathrm{C}$-aspirin to determine whether aspirin is a substrate of MDR1 in Caco2 intestinal epithelial cells. First, ${ }^{14} \mathrm{C}$-aspirin was added to the AP side of the Transwell insert, and the concentration of aspirin was monitored in the BL side with and without verapamil. The BL concentration of aspirin was increased in a time-dependent manner after the administration of aspirin in the AP side. $\mathrm{P}_{\text {app }}(1.31 \pm 0.15)$ was significantly increased by the presence of verapamil (1.47 \pm 0.09$)$. Next, we performed the transport experiment in the opposite direction (adding ${ }^{14} \mathrm{C}$-aspirin into the BL side and monitoring the AP side). $\mathrm{P}_{\text {app }}$ was significantly increased in the BL to AP direction when compared with the AP to BL direction, and the efflux ratio was 4.28. In addition, the efflux ratio decreased in the presence of the MDR1 inhibitor, verapamil. 
These results clearly indicate that aspirin efflux occurs through the MDR1 transporter, because the efflux ratio was greater than 2 .

Finally, we compared the intracellular aspirin concentrations between the control and MDR1 $1^{\text {High }}$ Caco2 cells after treatment with aspirin. The present results showed that the concentration of aspirin in MDR $1^{\text {High }} \mathrm{Caco} 2$ cells was significantly decreased when compared with control cells and that the decrease in aspirin concentration was reversed by cotreatment with verapamil. These results also indicate that aspirin can enter into Caco 2 cells with passive diffusion and is pumped out from the cells by the MDR1 transporter. Since this study also showed that MDR1 plays a critical role in the pathogenesis of aspirin-induced apoptotic cell death of Caco2 cells, it is possible that MDR1 affects aspirin-induced cell death via regulation of intracellular aspirin concentrations. In fact, data from the present study suggest that induction of MDR1 in intestinal epithelial cells could suppress aspirin-induced small intestinal injury. However, we should stress that high expression of MDR1 in intestinal epithelial cells is not always good, because it has been reported that there is a positive correlation between $\mathrm{P}_{\text {app }}$ (AP to BL) and intestinal absorption of target drugs [13]. Aspirin can induce MDR1 expression in Caco2 cells [14]. Therefore, induction of MDR1 may be a self-defense system against intestinal epithelial cellular injury by decreasing cellular aspirin concentration. Further, disturbance of MDR-1 induction may be related to a high risk for aspirin-induced small intestinal injury. Sharma et al. [15] recently described the association between the C3435T MDR1 gene polymorphism and aspirin resistance. Further research regarding the relationship between MDR1 gene polymorphism and small intestinal injury in patients with prolonged use of aspirin would be of benefit.

In conclusion, the present study demonstrated that MDR1 plays a crucial role in the intestinal epithelial cell permeability of aspirin and in aspirin-induced apoptotic cell death. Further, MDR1 overexpression could prevent this type of cell death. Additional study to identify agents that can induce MDR1 expression in intestinal epithelial cells and prevent aspirin-induced intestinal injury would be of benefit.

\section{Acknowledgements}

This work was supported by a Grant-in-Aid for Scientific Research (C) to Y.N. (No. 22590705) and a Grant-in-Aid for Scientific Research (C) to K.U. (No. 24590665) from the Japan Society for the Promotion of Science; and an Adaptable and Seamless Technology Transfer Program through Target-driven R\&D to Y.N. from the Japan Science and Technology Agency. We thank Dr. Kohichiroh Yasui for reviewing this manuscript.

\section{Conflict of interest}

Yoshito Itoh and Nobuaki Yagi has an affiliation with a donation-funded department from AstraZeneca Co., Ltd., Eisai Co., Ltd., Otsuka Pharmaceutical Co., Ltd., MSD K.K., Dainippon Sumitomo Pharma Co., Ltd., Chugai Pharmaceutical Co., Ltd., FUJIFILM Medical Co., Ltd. and Merck Serono Co., Ltd. Yuji Naito received scholarship funds from Otsuka Pharmaceutical Co., Ltd. and Takeda Pharmaceutical Co., Ltd. Yoshito Itoh received scholarship funds from MSD K.K. and Bristol-Myers K.K. The other authors have no conflicts of interest to declare. 


\section{Cellular Physiology and Biochemistry}

Kugai et al.: MDR1 Transport Aspirin and Protect Epithelial Cell

\section{References}

1 Morimoto T, Nakayama M, Saito Y, Ogawa H: Aspirin for primary prevention of atherosclerotic disease in Japan. J Atheroscler Thromb 2007;14:159-166.

- 2 Endo H, Hosono K, Inamori M, Kato S, Nozaki Y, Yoneda K, Akiyama T, Fujita K, Takahashi H, Yoneda M, Abe Y, Kirikoshi H, Kobayashi N, Kubota K, Saito S, Matsuhashi N, Nakajima A: Incidence of small bowel injury induced by low-dose aspirin: A crossover study using capsule endoscopy in healthy volunteers. Digestion 2009;79:44-51.

3 Watkins PB: The barrier function of cyp3a4 and p-glycoprotein in the small bowel. Adv Drug Deliv Rev 1997;27:161-170.

4 Thiebaut F, Tsuruo T, Hamada H, Gottesman MM, Pastan I, Willingham MC: Cellular localization of the multidrug-resistance gene product p-glycoprotein in normal human tissues. Proc Natl Acad Sci U S A 1987;84:7735-7738.

5 Shiotani A, Murao T, Sakakibara T, Tarumi K, Manabe N, Kamada T, Kusunoki H, Haruma K: Association of slco1b1 $1 \mathrm{~b}$ with peptic ulcer amongst Japanese patients taking low-dose aspirin. Dig Liver Dis 2012;44:201-205.

6 Wallace JL: Prostaglandins, NSAIDS, and gastric mucosal protection: Why doesn't the stomach digest itself? Physiol Rev 2008;88:1547-1565.

7 Arakawa T, Watanabe T, Tanigawa T, Tominaga K, Otani K, Nadatani Y, Fujiwara Y: Small intestinal injury caused by NSAIDS/aspirin: Finding new from old. Curr Med Chem 2012;19:77-81.

-8 Endo H, Sakai E, Higurashi T, Yamada E, Ohkubo H, Iida H, Koide T, Yoneda M, Abe Y, Inamori M, Hosono K, Takahashi H, Kubota K, Nakajima A: Differences in the severity of small bowel mucosal injury based on the type of aspirin as evaluated by capsule endoscopy. Dig Liver Dis 2012;44:833-838.

-9 Nonoyama K, Nakagawa K, Amagase K, Takeuchi K, Nakamura M, Okabe S: New method of inducing intestinal lesions in rats by intraduodenal administration of aspirin. J Gastroenterol Hepatol 2010;25 Suppl $1: S 15-22$.

10 Needs CJ, Brooks PM: Clinical pharmacokinetics of the salicylates. Clin Pharmacokinet 1985;10:164-177.

11 Tomisato W, Tsutsumi S, Rokutan K, Tsuchiya T, Mizushima T: NSAIDS induce both necrosis and apoptosis in guinea pig gastric mucosal cells in primary culture. Am J Physiol Gastrointest Liver Physiol 2001;281:G1092-1100.

12 Ricchi P, Di Matola T, Ruggiero G, Zanzi D, Apicella A, di Palma A, Pensabene M, Pignata S, Zarrilli R, Acquaviva AM: Effect of non-steroidal anti-inflammatory drugs on colon carcinoma caco-2 cell responsiveness to topoisomerase inhibitor drugs. Br J Cancer 2002;86:1501-1509.

13 Zhao YH, Le J, Abraham MH, Hersey A, Eddershaw PJ, Luscombe CN, Butina D, Beck G, Sherborne B, Cooper I, Platts JA: Evaluation of human intestinal absorption data and subsequent derivation of a quantitative structure-activity relationship (QSAR) with the abraham descriptors. J Pharm Sci 2001;90:749-784.

-14 Jung KH, Chu K, Lee ST, Yoon HJ, Chang JY, Nam WS, Yoon SH, Cho JY, Yu KS, Jang IJ, Kim M, Lee SK, Roh JK: Prolonged use of aspirin alters human and rat intestinal cells and thereby limits the absorption of clopidogrel. Clin Pharmacol Ther 2011;90:612-619.

15 Sharma V, Kaul S, Al-Hazzani A, Prabha TS, Rao PP, Dadheech S, Jyothy A, Munshi A: Association of c3435t multi drug resistance gene-1 polymorphism with aspirin resistance in ischemic stroke and its subtypes. J Neurol Sci 2012;315:72-76. 